

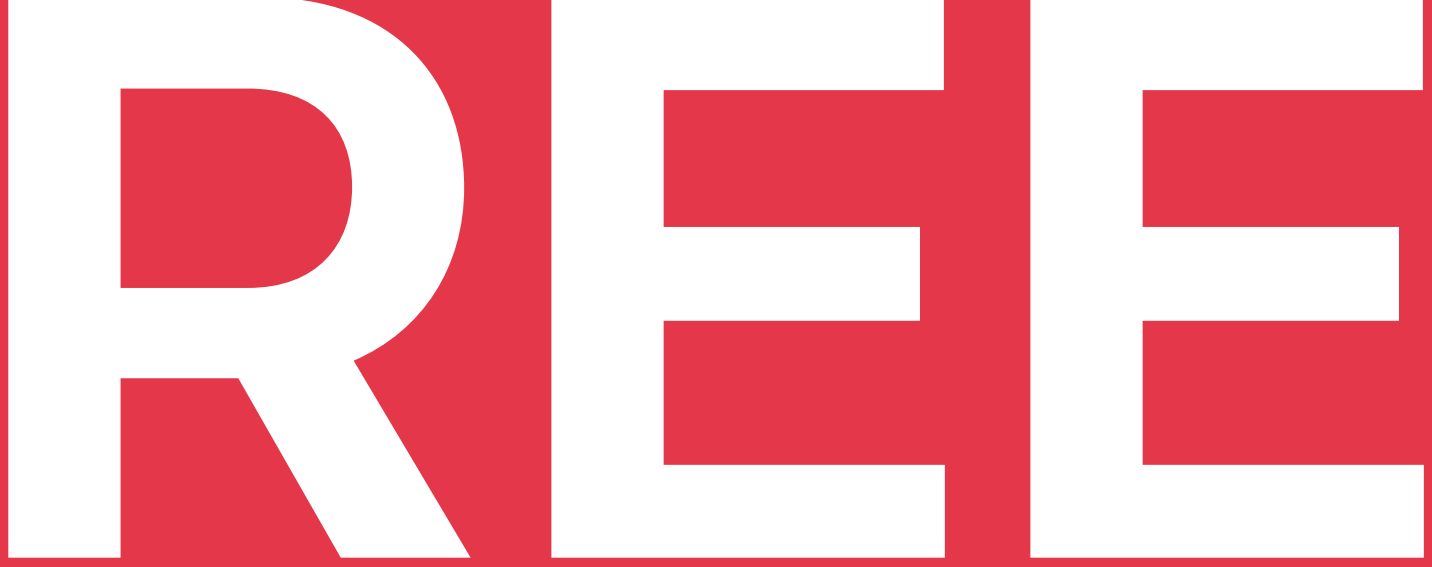

\section{CHAPTER 3: INTERNET MARKETING COMMUNICATIONS OF TRADE ENTERPRISES IN UKRAINE}

\section{Tetiana Dubovyk, Grand PhD (Economics)}

Professor, Department of Marketing and Advertising Kyiv National University of Trade and Economics

Kyiv, Ukraine 
It's necessary to make an accent that at the present stage of economic growth, the essential changes take place in the consciousness of the customer - customer became another one, his "market consciousness" increased. They have the higher level of goods and services quality expectations, strive for more convenient arrangement and working hours, better service, lower prices. Such situations were caused by the modern society development tends, changes in the way and style of people's life. Also the part of innovators, who endeavor to get goods, in which new ideas and technologies were embodied. It is also stipulated by the modern development temps and by implementation of information-communication technologies, and by the psychological factors.

Consumption of such goods becomes a symbol along with the buying of prestige goods; it demonstrates the high social status, shows progressiveness and contemporaneity of the customer. As the world experience shows the velocity of reaction on market changes is characteristic for small and midsize business, which are rather flexible to changes and opportunities of variable market conditions.

On today stage of economic development the majority of trade companies face with the market crisis, which is caused by globalizing processes, increasing competition, science-technology progress, consumer shift, his behavior and life style, the decrease of traditional marketing communications effectiveness, and also the increasing of society expectations about companies with great resources.

The information economy makes new demands on the formation of the internet-marketing communication that are able to continuously communicate with consumers, involve them in the process of interaction trade. The importance of internet-marketing communication (InMC) increases with increasing competition, and experts predict that over time they will play a leading role as the most progressive marketing system that is able to establish personal contacts with the target audience, offer individualized for each individual user. Ukraine ranks 34 among 201 countries in the number of Internet users [1].

Addressing the needs and wishes of potential and existing clients is indispensable in sustaining market success for a company; with increased international competition, companies must be focused to the individual specificities of consumers. With the increasing importance of online sales and the growing number of shoppers purchasing from online stores, it is imperative for marketers to develop a better understanding of Internet surfers and shoppers [2].

In international marketing activities, significant problems are often posed by differences in the characteristics and consumption behavior of consumers in different parts of the world. Certainly, some of these differences are becoming less important and some 
academics have the opinion that that they are no longer of great significance. However, there is also a lot of evidence that both cultural variance and differences in consumer behavior are still very important facts in many international markets $[2,3]$.

There is virtually a consensus that, to remain competitive, firms must continuously develop and adapt their business models [4]. However, it is believed that all users are equal and equally creative, particularly in relation to the so called Web 2.0 culture in which everyone is defined as being a participant in new Internet services [5,6]. However, several studies have demonstrated that people with similar levels of access engage the Internet in fundamentally different ways [7].

Kollmann, T., Kuckertz, A., \& Kayser, I. (2012) develop and empirically analyze a typology of customers to classify distinct segments of consumers, highlighting the associated interrelationship of individual shopping motives and cannibalization and synergetic effects [8].

S. Ghose and W. Dou (1998) have examined what the Web offers by doing a study of the impacts of web site design features on site quality [9]. Convenience in shopping is one of the most obvious advantages. Similarly, the ease with which information can be accessed is also strength of the online environment. Security of information is a primary worry for potential e-commerce consumers. Ph. Kotler (2002) also mentions that consumers have ethical concerns about Internet vendors [10]. Research results clearly show that attitudes towards the Internet and Internet shopping behavior differ from country to country $[2,11]$.

In this global environment, consumer typologies may prove an effective instrument for identifying and addressing different consumer clusters. A similar approach has been considered to be highly relevant for Internet marketing [12,13]. In trade articles, customer segmentation is described as crucial for the success of electronic commerce. R. Burke (2002) points out that an important unanswered research question relates to how retailers can segment online shoppers [14]. Only through an understanding of the different customer segments will marketers be able to develop strategies and tactics to attract and maintain these customers [2].

However, as yet, only a few typologies of Internet users exist, such as those of the Boston Consulting Group or McKinsey \& Co., and these have not been developed in accordance with academic standards of research $[2,15]$.

The paper uncovers issues of methodological, scientific and practical marketing investigations approaches basic target segments of consumers and proposes the possible use of the components of Internet marketing communication for these segments of consumers. 
The Internet occupies the basic position among all the information technologies, which growth leads to the necessity of trade enterprises products and services promotion, the search of information, customers and partners, and also the profit of internet-technologies application. All the mentioned need almost new means of internet-marketing, including marketing communications, which can give an opportunity to make a considerable reduce of marketing budget and provide more effective affairs of trade enterprise with consumers, competitors, intermediates, providers and other social circles.

\section{METHOD}

The author conducted a marketing research. The purpose of the study was to identify the factors that influence the management of online marketing communications of trade enterprises. The task of marketing research definition: the purpose of creating online stores; marketing communication goals of the site / online store; the activity of the company is strictly the work with consumers and their responses; evaluating Internet marketing activities of online stores; features used to monitor the effectiveness of Internet marketing communication activities; obstacles to rising costs for Internet marketing communications; information provided on the site / online store; the presence of online stires in social networks.

The general statistics on the number of online stores, their turnover and, moreover, the division of food and non-food by the State Statistics Service of Ukraine is not conducted. It should be noted that by the end of 2016 there were about 45 thousand representatives engaged in electronic commerce.

Of the general population, Internet stores that occupy less than $2 \%$ of the market share in the structure of the Internet trade market (textiles, cooking and eating, jewelry and art products etc.) and those with the smallest number of transactions and the number of visitors (less 500 per day). Also separately considered the online store "Rosetka", which occupies 35\% of the Internet market in the segment "Electronics and Appliances".

The survey was conducted in Kyiv, Ukraine (May-June 2017) on the basis of a quota sample representing online stores (food, non-food, mixed). The volume of the representative sample is 304 online-stores, which reflects the general population of this group. The statistical error of a random probabilistic sample of 304 units in the general population with a confidence probability of 0.945 does not exceed 0.055 (5.5\%). The sample interval was 33 . 
The appropriateness of the approach to the formation of the sample is substantiated: multi-stage, stratification, using the quota method of removing online stores at the last stage.

The study was conducted in 2 stages. In the first stage, 30 enterprises of the Ukrainian trade industry were analyzed and the main trends in the organization of Internet marketing communications were determined, the nature of which was analyzed in detail during the increase of the sample. At the second stage, the distribution of online stores - survey participants is the following data groups: goods for construction, repair and decoration of housing - 7.9\%; furniture - 5.6\%; electronics and appliances - 35.5\%; goods for storing, cooking and eating - 2,6\%; goods for sports and tourism - 13,5\%; clothing and shoes - 20,1\%; household and personal care - $2.3 \%$; goods for children 9.5\%; food and beverages $-3.0 \%$.

The results of the author's research revealed the factors that inhibit the use of Internet marketing communications for $35.20 \%$ of trading companies there is a budget constraint for all marketing activities, 34.87\% - legislative and regulatory restrictions, $33.55 \%$ - shortage of skilled workers for implementation of these measures.

It is worthwhile to point out that for all types of enterprises, the material and technical base of the enterprise is a significant limiting factor, and in cases with online stores that specialize in food product - this factor reaches 55.56\%. In almost this percentage, factors affecting the legislative and regulatory restrictions on online stores specializing in goods for construction, repair and decoration of housing - 50.0\% (table1).

The analysis of the instruments of the InMC of trade enterprises has shown that most online stores tend to use search engine optimization for keywords, banner and multimedia advertising (table 2).

The results of the marketing research conducted by the author show that $59.2 \%$ of enterprises considered the generation of incomes and growth of sales as the main objectives of the management of InMC. However, for online stores specializing in clothing and shoes, children's products, home and personal care, the main goal of Internet marketing communications was to form and maintain relationships with target audiences of the Internet community.

The establishment of public relations as the target of InMC has chosen only $8.3 \%$ of online stores selling goods for construction, repair and decoration of housing. More than half of respondents (54.2\%) believe that optimizing the presence of an online stores is the best way to use search engine optimization for keywords. Trade companies specializing in the sale of goods for children, buy domain names to improve online trading. 
Tab. 1: Factors that constrain the use of the Internet marketing communications by online stores in Ukraine, $\%$

\section{Specialization of online stores}

\begin{tabular}{|c|c|c|c|c|c|c|c|c|c|}
\hline 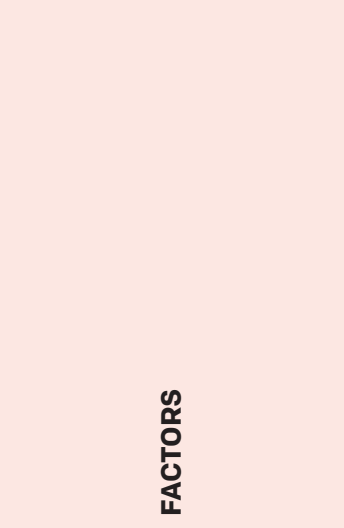 & 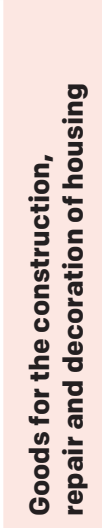 & 올 & 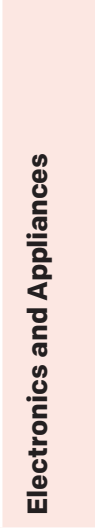 & 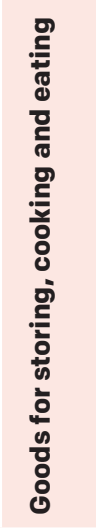 & 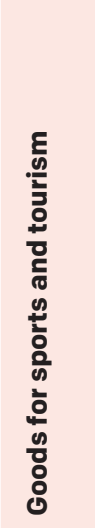 & 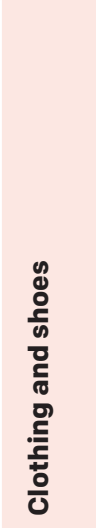 & $\begin{array}{l}0 \\
\frac{0}{6} \\
0 \\
\\
\\
0 \\
0\end{array}$ & 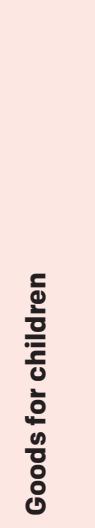 & 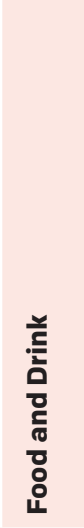 \\
\hline $\begin{array}{l}\text { Legislative and } \\
\text { regulatory constraints }\end{array}$ & 50,00 & 41,18 & 29,63 & 37,50 & 29,27 & 39,34 & 28,57 & 34,48 & 44,44 \\
\hline $\begin{array}{l}\text { Lack of the implementa- } \\
\text { tion of modern informa- } \\
\text { tion and communication } \\
\text { technologies into the } \\
\text { activity of the enterprise }\end{array}$ & 33,33 & 0,00 & 17,59 & 12,50 & 4,88 & 9,84 & 28,57 & 10,34 & 0,00 \\
\hline $\begin{array}{l}\text { Lack of special software } \\
\text { in the process of making } \\
\text { managerial decisions }\end{array}$ & 16,67 & 29,41 & 7,41 & 0,00 & 7,32 & 8,20 & 0,00 & 6,90 & 11,11 \\
\hline $\begin{array}{l}\text { Material and technical } \\
\text { base of the enterprise }\end{array}$ & 37,50 & 47,06 & 23,15 & 25,00 & 31,71 & 31,15 & 14,29 & 24,14 & 55,56 \\
\hline $\begin{array}{l}\text { Restriction of budget for } \\
\text { all marketing activities }\end{array}$ & 33,33 & 52,94 & 37,04 & 50,00 & 34,15 & 52,46 & 0,00 & 0,00 & 0,00 \\
\hline $\begin{array}{l}\text { Culture of entrepreneu- } \\
\text { rship }\end{array}$ & 0,00 & 0,00 & 7,41 & 0,00 & 0,00 & 0,00 & 0,00 & 3,45 & 0,00 \\
\hline $\begin{array}{l}\text { Insufficient skilled } \\
\text { workers to implement } \\
\text { these activities }\end{array}$ & 29,17 & 29,41 & 33,33 & 25,00 & 43,90 & 27,87 & 14,29 & 48,28 & 22,22 \\
\hline $\begin{array}{l}\text { Incompetence of emplo- } \\
\text { yees of the enterprise }\end{array}$ & 12,50 & 23,53 & 7,41 & 12,50 & 17,07 & 9,84 & 14,29 & 6,90 & 11,11 \\
\hline $\begin{array}{l}\text { Experience of conducting } \\
\text { InMC }\end{array}$ & 29,17 & 35,29 & 5,56 & 25,00 & 9,76 & 11,48 & 0,00 & 6,90 & 0,00 \\
\hline $\begin{array}{l}\text { Expecting an incredible } \\
\text { result after carrying out } \\
\text { these activities }\end{array}$ & 8,33 & 0,00 & 2,78 & 0,00 & 9,76 & 4,92 & 0,00 & 6,90 & 11,11 \\
\hline
\end{tabular}

Source: authors investigations, a national survey of 304 online-stores in Kiev, Ukraine, statistical error - 0,945doesn't exceed 0,055 (5,5\%). Investigations were provided in 2017. 
Tab. 2: Use instruments of InMC by online stores in Ukraine,\%

\begin{tabular}{|c|c|c|c|c|c|c|c|c|c|}
\hline \multicolumn{10}{|c|}{ Specialization of online stores } \\
\hline 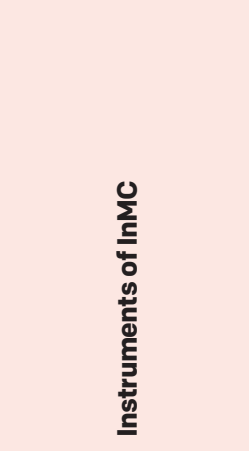 & 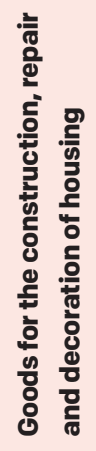 & $\begin{array}{l}\text { 놀 } \\
\text { 론 } \\
\frac{3}{3}\end{array}$ & 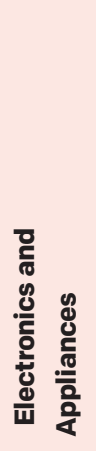 & 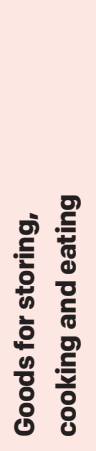 & 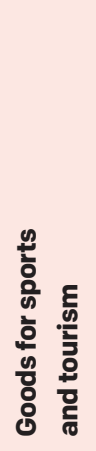 & 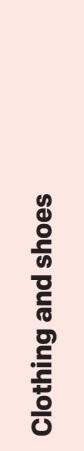 & 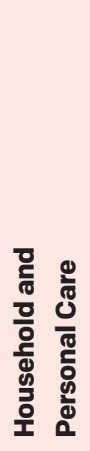 & $\begin{array}{l}\frac{c}{0} \\
\frac{2}{0} \\
\frac{\bar{c}}{0} \\
0 \\
\frac{2}{2} \\
\frac{0}{0} \\
\frac{0}{0} \\
8 \\
0\end{array}$ & 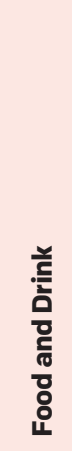 \\
\hline $\begin{array}{l}\text { Key words } \\
\text { search engine } \\
\text { optimization }\end{array}$ & 87,5 & 76,5 & 83,3 & 75,0 & 87,8 & 88,5 & 57,1 & 86,2 & 55,6 \\
\hline $\begin{array}{l}\text { InMC in social } \\
\text { networks }\end{array}$ & 37,5 & 64,7 & 32,4 & 15,6 & 61,0 & 77,1 & 28,6 & 72,4 & 33,3 \\
\hline $\begin{array}{l}\text { InMC appeal } \\
\text { content }\end{array}$ & 66,7 & 64,7 & 48,2 & 18,8 & 80,5 & 85,3 & 71,4 & 58,6 & 44,4 \\
\hline $\begin{array}{l}\text { E-mail of sending } \\
\text { inquiries to InMC }\end{array}$ & 12,5 & 17,7 & 70,4 & 6,3 & 70,7 & 52,5 & 42,9 & 55,2 & 44,4 \\
\hline $\begin{array}{l}\text { InMC on mobile } \\
\text { devices }\end{array}$ & 33,3 & 11,8 & 63,9 & 6,6 & 39,1 & 0,0 & 28,6 & 69,0 & 11,1 \\
\hline $\begin{array}{l}\text { Banners, } \\
\text { multimedia and } \\
\text { online advertising }\end{array}$ & 66,7 & 52,9 & 80,6 & 12,5 & 85,4 & 54,1 & 28,6 & 72,4 & 44,4 \\
\hline InMC in webinars & 0,0 & 0,0 & 2,8 & 0,0 & 0,0 & 0,0 & 0,0 & 0,0 & 0,0 \\
\hline $\begin{array}{l}\text { InMC in affiliate } \\
\text { programs }\end{array}$ & 12,5 & 5,9 & 17,6 & 0,0 & 0,0 & 19,7 & 14,3 & 17,2 & 11,1 \\
\hline $\begin{array}{l}\text { Price comparison } \\
\text { sites }\end{array}$ & 54,2 & 47,1 & 89,8 & 9,4 & 53,7 & 68,9 & 57,1 & 55,2 & 55,6 \\
\hline Forums / chats & 25,0 & 0,0 & 39,8 & 0,0 & 19,5 & 6,6 & 0,0 & 55,2 & 0,0 \\
\hline $\begin{array}{l}\text { PR in the Internet } \\
\text { (articles, video- } \\
\text { conferences) }\end{array}$ & 12,5 & 11,8 & 19,4 & 6,3 & 0,0 & 4,9 & 14,3 & 10,3 & 0,0 \\
\hline $\begin{array}{l}\text { Participation in } \\
\text { professional client } \\
\text { discussion clubs }\end{array}$ & 0,0 & 0,0 & 20,4 & 0,0 & 0,0 & 9,8 & 14,3 & 37,9 & 0,0 \\
\hline $\begin{array}{l}\text { Sponsorship } \\
\text { in Internet }\end{array}$ & 0,0 & 0,0 & 13,0 & 0,0 & 0,0 & 6,6 & 0,0 & 13,8 & 0,0 \\
\hline Virtual exhibitions & 0,0 & 5,9 & 4,6 & 0,0 & 0,0 & 4,9 & 0,0 & 3,5 & 0,0 \\
\hline $\begin{array}{l}\text { Promotions, sales, } \\
\text { the Internet prizes } \\
\text { raffling }\end{array}$ & 25,0 & 11,8 & 34,3 & 0,0 & 17,1 & 29,5 & 42,9 & 41,4 & 22,2 \\
\hline $\begin{array}{l}\text { Links to the site } \\
\text { for relevant tests / } \\
\text { reviews }\end{array}$ & 25,0 & 0,0 & 31,5 & 3,1 & 7,3 & 23,0 & 14,3 & 27,6 & 11,1 \\
\hline
\end{tabular}

Source: authors investigations, a national survey of 304 online-stores in Kiev, Ukraine, statistical error - 0,945doesn't exceed 0,055 (5,5\%). Investigations were provided in 2017. 
The results of the provided by authors marketing investigation, evidence that respondents indicated the most essential features of the internet-stores: the wide choice, price level, the ability to compare the products' characteristics, prices, promotions, sales, customers and experts reviews, forums discussions. The differences in the price range are actively tracked by customers of 30-39 years old - 85,7\%, and by customers of 40-55 years old $-83,7 \%$. For the customers $(86,5 \%)$ with the high income the most determinant option in choosing the internet-store is the rapidity of delivery. The available video review and receiving the supply information appeared less essential.

The Internet posts (experts' reviews, blogs, and forums), online-stores web-sites, comparison sites and social networks information are the most significant of all the information sources, which influence the decisions of customers - to buy or not to buy goods in online-stores.

\section{RESULTS}

The personalized approach to plan the internet-marketing communicative companies of trade enterprises, and also to define the perspectives of their improvement are based on the using of methodological approaches to the process of Internet users segmentation, so it provides the formation of integrated online-marketing communications considering the influence of online-marketing communications on the target customers segments.

There are models of consumer behavior VALS (based on hierarchical theory of needs Maslow), VALS-2 (consumers are based the choice on their beliefs, their perception, action) and financial, informational, physical, psychological resource consumers. Developed SRI International model iVALS (Internet VALS) (1997) helped to improve the efficiency and quality «online» - environment. Depending on the activity and the professional skills of the Internet users are divided into groups: wizard, pioneers, surfers, mainstreamers, upstreamers, workers, sociables, socialites - seekers, immigrants. However, these models do not take into consideration specific features and actions of domestic consumers in terms of extremely rapid development of the Internet in Ukraine. The segmentation process of the Internet users must be based on the monitoring of the activity in social networks, on the customers awareness of personal data value considering the forecast influence of online-marketing communications on customers target segments [16,17].

The approved expediency of specific consumer segments isolation - those, who constantly look for the sought-for information in the Internet; have an experience in information search, look for the conditions of purchase, look for the low prices, look for the information in the Internet for the first time.

The target groups of consumers were formed by the base segmentation criteria 
(a set of factors, which influence the consumers' decision making, the probability of Internet purchase, and the social networks as a communication mean, the personal data confidentiality management, the customers' awareness of personal data value). Motivated segmentation allows specialists make propositions of argumentative InMC instruments and main themes of online-marketing appeals.

For the results the target consumers segments were detected (Table 3). It is suggested to apply the customized approach to the defining of the most acceptable for the target audience forms of and methods of online advertising, the system of stimulating in the Internet, online merchandising, PR in the Internet, direct sales in the Internet; during the process of the Internet online-marketing communication program development; it is also suggested to apply the bench marketing methods for the InMC programs development. It is recommended to increase the competitiveness of enterprises by the implementation InMC means into the marketing activity, based on the "virus" online-marketing; consistent inner corporate coordination, which provides the coordinated work of all the departments, which take part in development or realization of InMC programs.

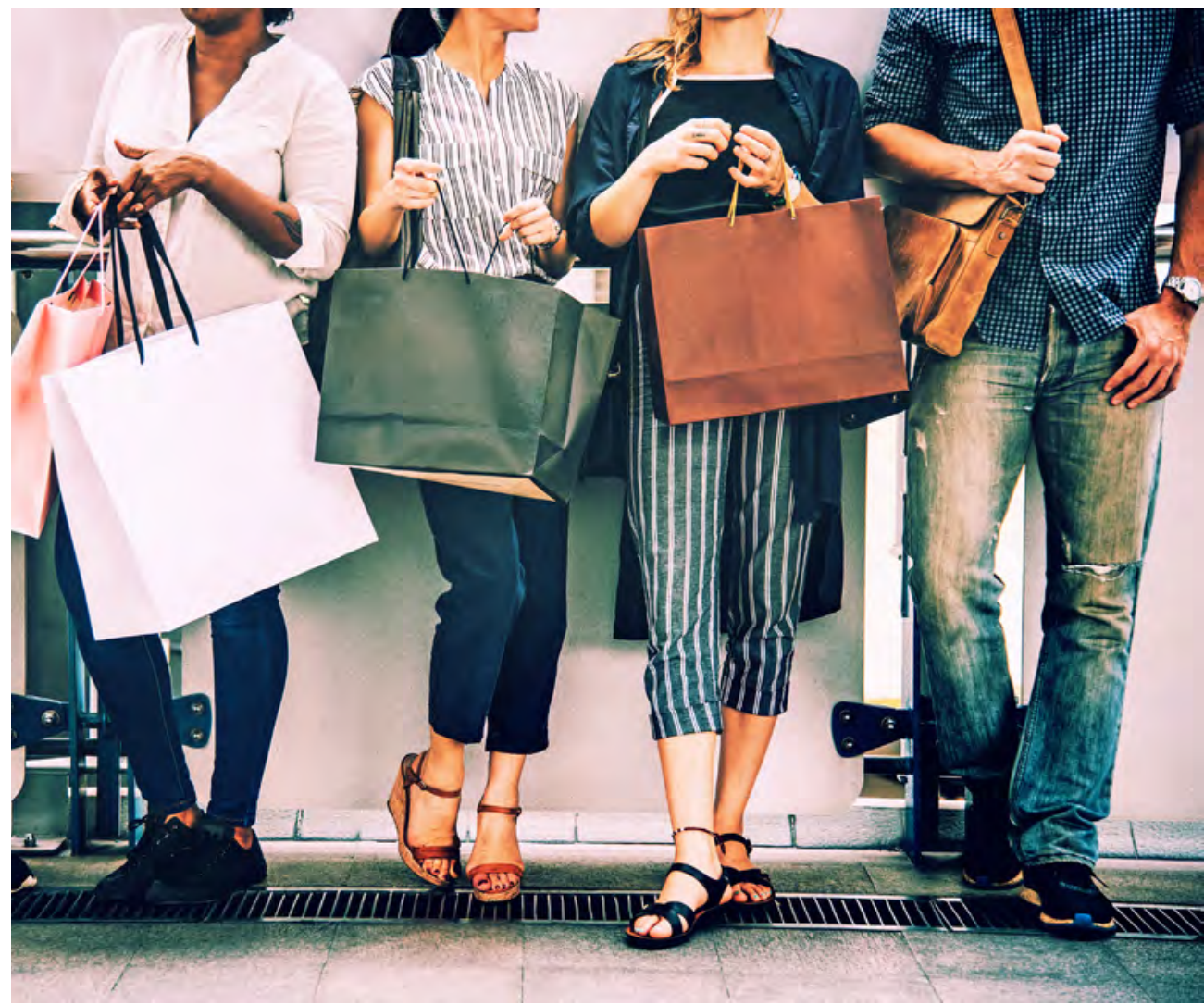


Tab. 3: Application of the internet-marketing communications to implicate Ukrainian consumers [The authors's development]

Target segments characteristics

Characteristics

Set of factors, which
influence the consumers
decision making concerning
buying products in the
Internet

Probability of the Internet purchase

Social networks for communication

Data privacy management

The customers' awareness of personal data value

\section{Price hunters}

- The wide range of products

- Competent and common style of product review

- The web site design (color, font, etc.)

- Product photo

- Video review

\section{High}

Very often

In comparison with other users they are more disposed to make purchases by means of mobile devices and to share personal data, but expect the future profits in return

Not enough recognition
Interested

- Information about the online-stores charts

- The wide range of products

- Clients, experts responds and forums discussions
They don't conceive the value of the personal data and don't express the concern about it

\section{Internet-marketing communications components}

\section{The main topic in InMC} content appeals
Technical and semantic logic
The expert support of specific information search
The most important instruments of InMC, which should be used by the trade enterprises
- Key words search engine optimization

- InMC appeal content

- $\quad$ InMC in social networks

- Price comparison sites

- InMC on mobile devices

- Banners, multimedia and online advertising
No recognition

\section{Seldom}

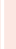

\section{Low}


Finders ("searchers")

- Conditions and different ways of payment

- The possibility to compare the product quality characteristics

- Easy order

Middle

Often

They know that social networks can use the personal data to inform about the special deals

\section{Observers}

- Price level

- The possibility to compare the product quality characteristics, prices, special offers

- $\quad$ Special offers, sales
Freshers ("tiros")

- The reputation and the popularity of online-store

- The safety level of the site

- The relevance of contacts

- Handy browsing

- $\quad$ The velocity of site uploading

- Friends advice

- The availability of reliable information

\begin{tabular}{l|l} 
Middle Low & Low
\end{tabular}

Often

They share their personal data and expect the access and propositions profit in return

Recognition
Seldom

They have protected personal settings and know, how to change the confidentiality settings on computer and mobile devices

Full recognition
More recognition then its absence
Compliance with announced obligations

- $\quad$ Site navigation

- Banners, multimedia and online advertising

- InMC in partnership programs

- Price comparison sites

- Lead generation
Sales

\section{Protection of data privacy}

- $\quad$ Site navigation

- Professional club membership

- $\quad$ Links for the appropriate tests and reviews

- $\quad$ PR in the Internet (articles, video-conferences)

- Forum/chat

- Personal assistant 


\section{Discussions}

it is proved that in the future in Ukraine there will be an increase in e-commerce due to a number of factors: firstly, the activation of e-commerce in the regions of Ukraine; and secondly, the growth of online sales in Kyiv and in the cities of millions (with the emphasis shifted to commodity groups that were not previously in the top five - clothing and shoes, goods for childrens, cosmetics and perfumery, food products; thirdly, new players will enter the market (online retailers of chain retail trade stores) and, as a result, will increase competition, introduce new technologies, lower prices, and improve the quality of customer service.

According to the results of the research, typical problems of online stores of Ukraine were identified:

- Visitors leave the site in the first seconds without buying anything; users add items to the basket, but do not place orders;

- Customers execute orders but do not pay for it; visitors do not want to register in an online store;

- Contextual advertising does not work due to rigorous concurrency; price competition does not cover a significant portion of profits;

- $\quad$ Shares and discounts do not work properly or do not work at all;

- Mostly buyers make a purchase once on the site;

- Sales on the site are carried out without taking into account the specific features of the buyer;

- $\quad$ Standard pricing does not allow you to earn extra profit.

Thus, based on the systematization and synthesis of the literature and developments authors found that trading enterprises that operate offline and online have to respond to ongoing changes in consumer behavior, improving information and technological environments. Thesis there is determined consumer segments who, always in a constant search of information; has experience in information search; choose the easy way to buy; looking for the lowest prices; searches information for the first time. Target consumer group formed by the basic criteria for segmentation (a set of factors that influence the decision of consumers to purchase items online, chances shop online, use social networks for communication, privacy controls data, understanding consumer values personal data), there are tools InMC and the main topics of Internet marketing communication applications. 


\section{REFERENCES}

Internet Users by Country (2016). http://www.internetlivestats.com/internet-users-by-country/ Barnes, S. J., Bauer, H. H., Neumann, M. M., \& Huber, F. (2007). Segmenting cyberspace: a customer typology for the Internet. European Journal of Marketing, 41(1/2), 71-93.

Donthu, N. and Garcia, A., (1999) "The Internet Shopper", Journal of Advertising Research Vol. 39, No. 3 52-58.

Wirtz, B. W., Schilke, O., \& Ullrich, S. (2010). Strategic development of business models: implications of the Web 2.0 for creating value on the Internet. Long Range Planning, 43(2), 272-290.

Brandtzæg, P. B., Heim, J., \& Karahasanović, A. (2011). Understanding the new digital divide - A typology of Internet users in Europe. International journal of human-computer studies, 69(3), 123-138.

Van Dijck, J.D. (2009). Wikinomics and its discontents: a critical analysis of Web 2.0 business manifestos. New Media \& Society, 11 (5), 855-874.

Hargittai, E. (2010). Digital Na(t)ives? Variation in Internet skills and uses among members of the "Net Generation". Sociological Inquiry, 80 (1), 92-113.

Kollmann, T., Kuckertz, A., \& Kayser, I. (2012). Cannibalization or synergy? Consumers' channel selection in online-offline multichannel systems. Journal of Retailing and Consumer Services, 19(2), 186-194.

Ghose, S. and Dou, W. (1998). Interactive functions and their impacts on the appeal of Internet presence sites. Journal of Advertising Research, 38 (2), 29-43.

Kotler, Ph., Roberto, Lee, N. (2002). Social Marketing: Strategies for Changing Public Behavior. Thousand Oaks, CA: Sage Publications.

Hofstede, G. (1991) Cultures and Organizations: Software of the Mind. McGraw-Hill, London.

Lynch, P. D., Kent, R. J. and Srinivasan, S. S. (2001), "The global Internet shopper: evidence from shopping tasks in twelve countries", Journal of Advertising Research, Vol. 41 No. 3, pp.15-23.

Bhatnagar, A. and Ghose, S., (2004) "A Latent Class Segmentation Analysis of E-Shoppers," Journal of Business Research Vol. 57, 758-767.

Rohm, A. J. and Swaminathan, V. (2004) "A Typology of Online Shoppers Based on Shopping Motivations," Journal of Business Research Vol. 57, No. 7: 748-758.

Burke, Raymond R. (2002) "Technology and the Customer Interface: What Consumers Want in the Physical and Virtual Store," Journal of the Academy of Marketing Science, 30, 411-432.

Monsuwé, T.P.y., Dellaert, B.G.C. \& Ruyter, K.d. (2004) What drives consumers to shop online? A literature review. International Journal of Service Industry Management, 15(1), pp.102-21.

Dubovyk, T. (2014) Integreted internet-marketing communications. The economic annals $-X X I$, 116-119. (in Ukr.). 